\title{
Challenges and Countermeasures of Ideological and political education of minority college students in the new era
}

\author{
Gui LV \\ Nanchang Institute of Science \&Technology, Nanchang 330108,China
}

Keywords: New era; minority college students; ideological and political education

\begin{abstract}
In the new era, the new media as a new platform for information exchange and interpersonal communication, it provides new opportunities for the ideological and political education in colleges and universities, but it also increases the difficulty of education. Based on the particularity of minority college students and special task of ideological and political education from the perspective of analysising the minority college students ideological and political education, to adhere to the mainstream ideology, Marx's "five views" education, moral responsibility of cultivating faced the challenges, and from the correct guidance of public opinion, build a newwork platform for media of ideological and political education, the innovation of the ideological and political education management mode and the strengthening of the new media supervision and other aspects, and put forward some suggestions to enhance the effectiveness of ideological and political education of ethnic minority college students.

The most obvious feature of the new era is the rapid spread of information. New media is relative to the concept of traditional media, the Internet, mobile communication technology as the support of the media. Compared with the traditional media, the new media has the following characteristics: real-time, open, personalized, sub public, the mass of information, low cost global communication, search convenient, convergence, etc.. The position of the traditional media transmission and the receiver is very clear, transfer is released and disseminators of information, the recipient is received passively only, no matter how personal hobby, almost impossible to express their views on the information. But the new media and the transfer line between the transmitter and receiver of the blur, the recipient is not a passive receiver, and the transmission function and interactive information, and it also become a producer and disseminator of information. It is precisely because of this characteristic that the new media in the majority of internet users quickly spread.
\end{abstract}

\section{The particularity of ideological and political education of minority college students}

Minority students are special groups of college students, it is precisely because of this particularity that the minority students in colleges and universities occupy a very important position in the college students. On the one hand, they are the economic and social development in ethnic regions of China talent reserve sources, their ideological and political quality is very important to fly in ethnic areas and juvenile prosperity; on the other hand, because of the characteristics of ethnic minority areas of social environment and the students themselves, the ideological and political education of ethnic minority college students is more complex and special.

The particularity of the object of ideological and political education. Minority college students are mostly from the remote location, economic development is relatively backward areas, each nation has its own unique history and culture, therefore, in the new period, to carry out ideological 
and political education work in colleges and universities must consider the particularity of minority college students in the elephant.

The unique cultural psychological characteristics. Due to the minority special historical and cultural traditions, social development and education, as well as the unique local customs and practices and national psychological quality, compared between Han students and minority students, in the cultural psychological characteristics have significant differences. First, to strengthen national consciousness, awareness of the ethnic minority students are not objective enough, about weakening the national consciousness of the students of nearly $40 \%$; second, learning motivation due to show different, but the motivation is not strong situation is still prominent; third, the lack of initiative competition consciousness, prone to inferiority mentality, influence the development of the initiative. Cognitive level is relatively low. Cognitive level is a person's ability to understand, judge and evaluate the outside world,

The cognitive level is related to the factors such as knowledge level, thinking ability, information reserves and practical experience, which is one of the subjective factors that influence the formation and development of a person's thought. Due to the historical background, economic development, natural environment and other reasons, ethnic areas have lagged behind in the cultural and educational aspects, and the cognitive level of minority students is low. Although since the development of the western region, the basic education in minority areas in the infrastructure and basic condition of hardware with the eastern developed provinces in the gap reduced year by year, but in the education idea, education level and education quality of such software is worrying. This directly led to the minority college students face greater pressure to learn. Cognitive level will determine the students in the complex and changeable, the tide of information, easy to use experience to determine the choice, lack of rational thinking and analysis ability, lack of identification.

\section{The particularity of Ideological and political education task.}

The key to the national work of the party and government is to train the talents of ethnic minorities. Therefore, the ideological and political education of ethnic minority college students should not only follow the general educational policy of the country, but also reflect its particularity.

Service national strategy. Due to the special geographical location, ethnic areas are often the national strategy to safeguard national unity and oppose the forefront of the infiltration of hostile forces. Western hostile forces often use the nation, religion, the implementation of the differentiation of young students, westernization conspiracy, endangering the stability of ethnic areas, undermine the reunification of the motherland. Today, it is the use of new media and the right to speak, to discredit and attack the socialist ideology guided by Marx. Therefore, the ideological and political education of minority college students, the focus is deep publicity and vigorously promote the socialist core value system and core values, firmly grasp the initiative in ideological work, to maximize the cohesion of ideological consensus of various national students, cultivate their active service national strategy, safeguard national unity and national unity of responsibility consciousness.

Serving the development and inheritance of national culture. Because of the natural and close relationship between culture and nation, culture has become the soul of a nation's survival and development, and the source of power and vitality of a nation's prosperity and development. For a long time, due to the limited space and historical reasons, the culture of ethnic minorities in China is in a relatively weak position. The modernization of a nation should be marked by the inheritance and development of culture, as the leader of the nation, the minority college students are the 
important talents to develop and inherit the excellent cultural resources of the nation. Therefore, through the development of national consciousness education, to improve the minority college students in the cultural heritage of the national initiative and consciousness, to carry forward the fine traditional culture of the Chinese nation and enhance self-confidence and pride. The transformation of ethnic culture to modern promoter and practitioner. At the same time, to strengthen the traditional culture of the Chinese nation in the history of modern education, China education, enhance the identity of the Chinese nation, to enhance the sense of identity of the Chinese nation, the Chinese culture and People's Republic of China, as a promoter of national unity and social harmony.

\section{The challenge to the ideological and political education of minority college students}

Stick to the challenge of mainstream ideology. The rapid development of new media, for the contemporary college students to learn, to bring great convenience, and meet their diverse needs of life. The new media to break the restrictions of time and space, so that students access to information more convenient, but western hostile forces to use the network wantonly spread of non mainstream cultural statements and information provided convenience.

The challenge of cultivating social responsibility. Because of its concealment in the transmission of the new media, very easy to cause some students one-sided that the new media is a free place relative to democracy, whether it is praise or black brush, are not assume moral and social responsibility. Objectively speaking, the new media has the characteristics of digitalization and virtualization, makes some students more to indulge themselves, side revealed the evil of humanity, and moral norms in the society is difficult to restrain people in the virtual world of words, resulting in lack of network personality. This will further exacerbate the sense of social responsibility in real life fade and even decay, which has become a reality problem to be solved for the ideological and political education.

\section{Ideological and political education of minority college students under the background of new media}

Innovation of ideological and political education management model. College administrators should strengthen the effective supervision of all kinds of propaganda platform, information carrier and speech space, advocate fine management idea, and apply it to the field of ideological and political education. Point to point, one to one and more interactive functions as a powerful new medium between the ideological and political education of the "speaker" and "listener" communication becomes more and more open and equal. One to one, point to point communication mode is more suitable for minority college students' Ideological and political education. The workers of Ideological and political education of minority college students according to the characteristics of a purposeful and targeted exchange and education, in accordance with their aptitude, abandon the mode of education in the light of its general trend, people. Especially in the depth of a certain degree of understanding, the ideological and political educators can be based on the characteristics of the physical and mental development of college students, the development of more targeted educational programs, the use of fine education mode of the "tailored" the ideological and political education for minority college students and its effect was more prominent and significant.

Promote the construction of new media system, strengthen the new body of supervision. In the new media environment, to strengthen the internet in the legal and institutional level innovation, establish perfect internet legal and ethical norms, clear legal and moral anomie in the category of 
speech, limit commercial and entertainment vulgar speculation, on the internet in the designated "red line, indicating the area, plus the high voltage line. The implementation of new media access system, regulate the media's communication behavior. Two is the technical innovation. The establishment of suitable for young people to browse from the media, hierarchical classification for different objects to read the cultural information, filtering distortion information or harmful information. The three is to deal with the relationship between "sparse" and "guide". Through law, management, technology and education and other ways to strengthen the management of college students network behavior, improve the regulatory mechanism. In order to establish network regulations and management more perfect, to network information platform in the school set up a "firewall", timely closure of bad information, filter harmful information, good information related population. New media as the biggest change in ideological and political education, we must adhere to the combination of management and construction, good management to make good use of the new media as the biggest variable is become the biggest opportunity.

The main position to seize the new body, adhere to the correct orientation of public opinion. As the college ideological work frontier, shouldering the study Publicity of the Marx doctrine, cultivate and promote the socialist core values, to provide an important task of human resources and intellectual support for the realization of the great rejuvenation of the Chinese nation China dream. Yin in the process of Ideological and political education, to make full use of the main position of campus network of new media, increase the education theory and policy advocacy, training of ethnic minority college students in the right of the nation and religion, to guide students to learn to analyze the ethnic problems with the basic theory of the Marx doctrine, to let students understand many of the ethnic issues the essence of religion, is a major political struggle against secession from the. It is related to the consolidation of the ruling position of the Communist Party of China, the fundamental interests of the country and the Chinese nation, and the maintenance of national unity and social stability. Through the different content and the way of education, we must stimulate the students' national consciousness, strengthen the building the sense of responsibility of the countryside, and pay attention to the cultivation of students' healthy national consciousness, to prevent and eliminate the narrow nationalism. To be creative with the new media tools, make full use of voice, image, text and other educational resources, micro-blog, WeChat, QQ and other media means, deep publicity and vigorously promote the socialist core value system and core values, initiative, initiative and the right to speak firmly grasp the ideological work, leading diversified the social consciousness with the guiding ideology, to maximize cohesion consensus of minority college students.

\section{Conclusion}

In short, in the new media era, ideological and political education workers should be proficient in all kinds of new media tools, the network occupied the position as soon as possible, to open new horizons in order to effectively carry out the ideological and political education to provide a new carrier and form a joint force online network of ideological and political education, to give full play to the ideological and political education work in the growth of ethnic minorities in College students.

\section{References}

[1] Wang X. Challenges and Countermeasures of the Ideological and Political Education of "Post 90s” College Students[J]. Journal of Tianjin College of Commerce, 2015. 
[2] Zhang X M. Characteristics,Challenges and Countermeasures of Ideological and Political Education in the Era of Micro-blog[J]. Journal of Huaihai Institute of Technology, 2012.

[3] Sun M X, Marxism S O. Countermeasures:Undergraduate Ideological and Political Education in Micro-blog Era[J]. Journal of Xuchang University, 2014, 19:321-349.

[4] Hongjun. On the Challenges and Countermeasures Faced in Ideological and Political Education in "Microblogging" Era[J]. Raúl Avila, 2011, 10(4):págs. 267-288.

[5] Mingjing J I. Challenges and Countermeasures of Ideological and Political Education in New Period[J]. Guide of Science \& Education, 2011. 